\title{
Significance of copepod emergence to benthic, pelagic, and phytal linkages in a subtidal seagrass bed
}

\author{
Keith Walters ${ }^{1}$, Susan S. Bell ${ }^{2}$ \\ ${ }^{1}$ Marine Institute, University of Georgia, Sapelo Island, Georgia 31327-9999, USA \\ ${ }^{2}$ Department of Biology, University of South Florida, Tampa, Florida 33620-5150, USA
}

\begin{abstract}
The role of meiobenthic copepod emergence in linkages among benthic, pelagic, and phytal habitats was examined in a subtidal seagrass (Thalassia testudinum) bed at the mouth of Tampa Bay, Florida, USA. On 4 dates the ability of emerging copepods to affect the density and composition of benthic and phytal assemblages was tested during $2 \mathrm{~h}$ periods of minimum and maximum emergence. Copepod exchanges between benthic and phytal habitats and the duration of pelagic excursions also were examined throughout a night by measuring settlement into 2 types of sediment traps and onto natural and defaunated seagrass blades. The ability of emerging fauna to disperse through the water column was determined from horizontal collectors. Changes in copepod densities and composition during periods of active emergence did not indicate an unequivocal exchange between sediment and seagrass blade assemblages. Copepod resettlement onto the sediments was greater during periods of increased emergence and suggested that emerging copepods typically did not remain in the water column for a prolonged $(>2 \mathrm{~h}$ ) time. The dispersal of copepods through the water column was haphazard and unaffected by prevailing currents. Species and habitat affiliation influenced both the dispersal and settlement behaviors of emerging copepods. Although appreciable numbers of sediment-associated copepods can enter and disperse through the water column, our results suggest that the effects of emergence on linkages between benthic, pelagic, and phytal habitats are minimal or limited in duration.
\end{abstract}

KEY WORDS: Benthic-pelagic-phytal coupling - Emergence · Meiobenthic copepods · Seagrass . Resettlement

\section{INTRODUCTION}

Adult and postlarval stages of sediment-dwelling invertebrates from diverse taxonomic groups periodically enter the water column in a variety of habitats (Walters 1988, Jacoby \& Greenwood 1989, Lewis \& Boers 1991), and this emergence may affect significantly both benthic and pelagic environments. Frequent and substantial emigrations of individuals from the sediments would influence density dependent processes that occur within benthic populations (see Service \& Bell 1987, Walters 1991). While in the water column, emerging metazoans might interact with organic aggregates (Shanks \& Edmondson 1990), phytoplankton (Decho 1986), zooplankton, and nekton (Robertson \& Howard 1978). The extended distances that emigrating adults could disperse would affect the spatial scales over which benthic population phenomena occur (sensu Wiens 1989). Current models of benthic community development that focus exclusively on larval recruitment (i.e. Underwood \& Fairweather 1991) also may need to be expanded to account for the effects of adult and postlarval recruitment.

Harpacticoid copepods numerically dominate emerging fauna in most habitats (Cahoon \& Tronzo 1988, Walters 1988, Armonies 1989), and a significant proportion of sediment-dwelling copepod assemblages frequently enter the water column (Walters \& Bell 1986, Walters 1991). Copepod emergence is influenced by ambient light levels (Armonies 1988a), tidal (Bell et al. 1988) or diurnal periods (Walters 1988, 1991), current velocities (Armonies 1988b), copepod densities (Service \& Bell 1987, Walters 1991), and species behaviors (Walters 1991). Possible reasons for harpacticoid 
copepods emerging from the sediments include mating (Bell et al. 1988), foraging (Decho 1986), or dispersal (Kurdziel \& Bell 1992).

The impact of emergence on benthic and pelagic environments will depend partly on the time spent in the water column, the distances dispersed, and the final destination for emerging copepods. Emergence effects would be limited if copepods entering the water column immediately resettled to the same position in the sediments. Historically, researchers have targeted the processes governing either movement into or settlement out of the water column, but not both (e.g. Armonies 1988a, Fegley 1988, Kern 1990, Walters 1991). Separate studies of copepod advection (Palmer $\&$ Gust 1985) and the colonization of defaunated sediments in hydrodynamically active habitats (Sherman \& Coull 1980, Chandler \& Fleeger 1983, Kern \& Taghon 1986, Fegley 1988) suggest a direct connection between pelagic dispersal and benthic recruitment. In unvegetated habitats a few studies have documented the simultaneous emergence and resettlement of copepods (Alldredge \& King 1980, Cahoon \& Tronzo 1988, Jacoby \& Greenwood 1988, 1989). Unfortunately, interpretations of results are hampered by 2 problems: (1) potentially biased settlement trap designs (e.g. Gardner 1980a, Butman 1986) that prevent an accurate assessment of the origin (emergence or advection) and rate of copepod settlement, and (2) trap deployments typically $>10 \mathrm{~h}$ that limit conclusions about the length of time emerging copepods spend in the water column. The resettlement of emerging copepods from a subtidal seagrass bed was examined in field mesocosms by Bell et al. (1989), but those results may not reflect normal behavior because the availability of natural substrates for settlement was limited $k<30 \%$ of the total surface area) and mesocosm isolation might have affected copepod behavior. Because of the restricted focus and technical limitations of past studies, little is known about the fate of emerging copepods after leaving the sediments in the field.

In vegetated habitats, understanding the connections among emergence, dispersal, and settlement is complicated by the presence of phytal structures. Above-ground phytal structures can alter patterns of near-bottom flow and affect settlement (Eckman 1983). Phytal habitats represent a potential destination for sediment-emerging copepods. Macrophytes also are populated by unique copepod species (Rutledge \& Fleeger 1994) and species that are capable of entering the water column (Hicks 1986, Palmer 1986, Kurdziel \& Bell 1992). Phytal copepods in seagrass habitats can disperse through the water column and colonize blades $>20 \mathrm{~m}$ from a source bed (Bell \& Hicks 1991, Kurdziel \& Bell 1992). Although copepod morphology can identify potential habitat preferences and behavior in seagrass beds, many species that reside on blades also emerge from the sediment (Bell et al. 1987). In mesocosms sediment-emerging copepods resettle onto seagrass blades (Bell et al. 1989), and Webb \& Parsons (1992) suggest benthic copepods readily colonize blades. The presence of phytal structures as an additional source of and sink for emerging copepods increases the complexity of possible linkages between benthic and pelagic environments.

In the present study we examine how emergence contributes to linkages among benthic, pelagic, and phytal habitats. Copepod densities and species composition in the sediments and on seagrass blades were determined during periods of minimum and maximum emergence to investigate exchanges between benthic and phytal habitats. Colonization of sediments and blades was examined during frequent nighttime intervals to compare simultaneously patterns of emergence with benthic and phytal resettlement and assess copepod persistence in the water column. Connections between copepod emergence and pelagic dispersal also were investigated. Our goal was to determine the fate of emerging meiobenthic copepods in seagrass habitats and evaluate whether emerging copepods represent a significant link among benthic, pelagic, and phytal habitats.

\section{METHODS}

Study site. All samples were collected from a subtidal seagrass bed adjacent to the eastern end of Mullet Key at the mouth of Tampa Bay, Florida, USA (Fig. 1). The study site was located within a gently sloping embayment predominated by extensive Thalassia testudinum König beds beginning ca $20 \mathrm{~m}$ offshore. The site is not exposed to wave action or intense tidal currents. In Mullet Key Channel (Fig. 1), the mean diurnal tidal range is $0.7 \mathrm{~m}$ and maximum current speeds are $<50 \mathrm{~cm} \mathrm{~s}^{-1}$. Current velocities within the vegetated study site located behind Mullet Key at least $1.5 \mathrm{~km}$ away from a main tidal channel (Fig. 1) were not measured directly in this study, but maximum velocities in similar seagrass beds average $<5$ to $6 \mathrm{~cm} \mathrm{~s}^{-1}$ (Hall pers. comm.). On average, sediments were fine sands with $<7.0 \%$ silt/clay and $<4.0 \%$ total organic content (Walters 1987).

Field collections. Copepod movements among benthic and phytal habitats were examined initially by comparing the densities and species compositions of emerging, benthic, and phytal assemblages in field collections. A reduction in densities for individual copepod species in the sediment coincident with increased numbers emerging and on seagrass blades would suggest movements between benthic and phy- 


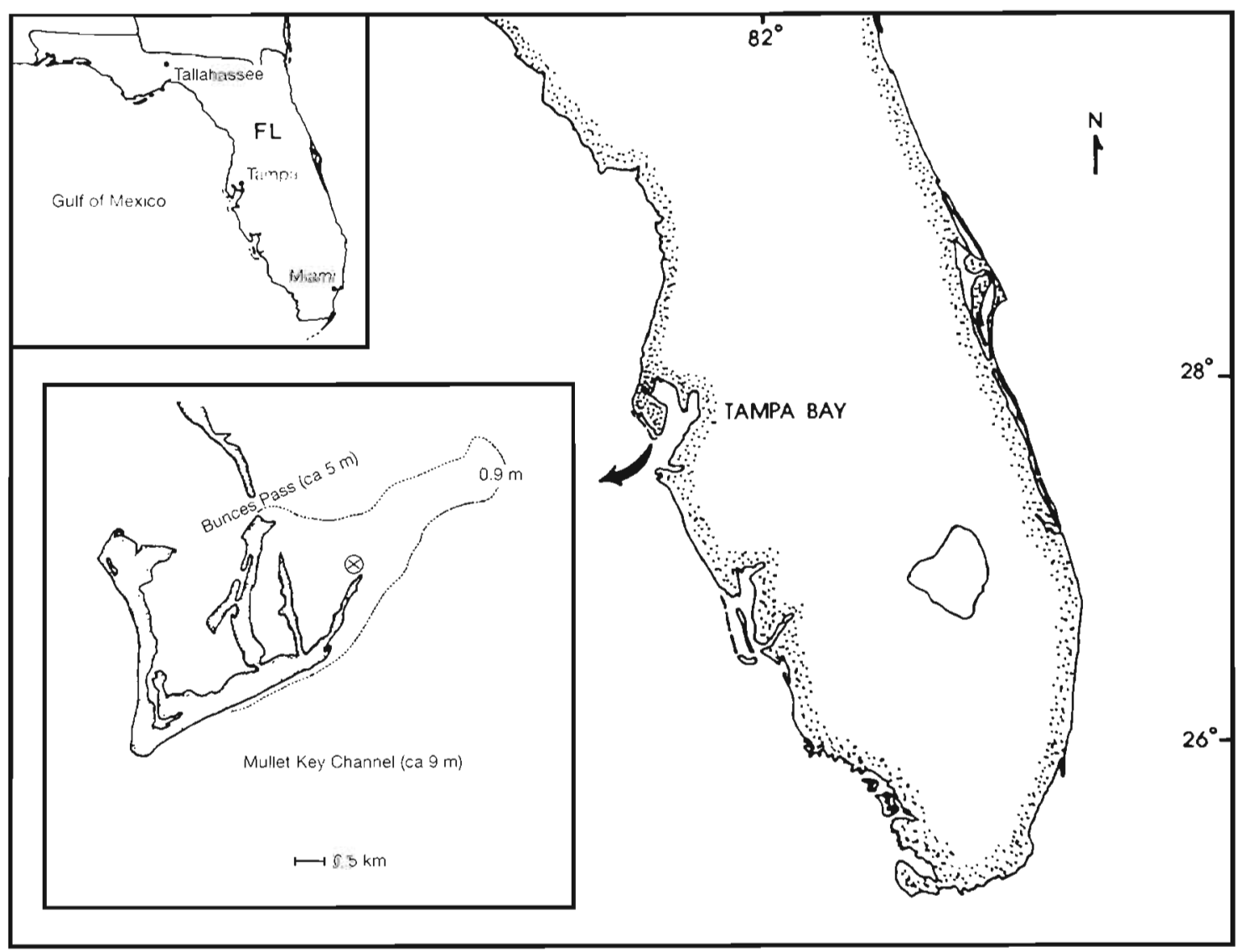

Fig. 1 Location of the study site $(\otimes)$ and major tidal channels at the mouth of Tampa Bay, Florida, USA

tal habitats. The distinct periodicity of emergence in subtidal seagrass beds (Walters 1988, 1991) enabled us to compare benthic and phytal densities and compositions during times when copepods were known to enter the water column.

Samples of emerging copepods and seagrass blades with associated fauna were collected from presunset and postsunset periods, times of minimum and maximum movement out of the sediments (Walters 1988, 1991), on 19 March, 20 May, 12 August, and 30 September 1983. Except for September, sediment samples also were taken and all sampling occurred within $2 \mathrm{~h}$ of high tides $(0.5$ to $0.6 \mathrm{~m}$ above MLW). Emergence samples were collected using traps described by Walters (1988) that consisted of an $82 \mathrm{~cm}^{2}$ PVC base, a clear acrylic catch-tube with an attached inverted funnel, and a $63 \mu \mathrm{m}$ mesh cap (Fig. 2). At the beginning of a sampling period, traps were positioned in the field between seagrass culms to exclude Thalassia testudinum blades and only sampled emerging, sediment-dwelling fauna. Organisms migrating $15 \mathrm{~cm}$ from the sediment surface and trapped in the catchtube were collected during $2 \mathrm{~h}$ periods. Some emer- gence data have been presented earlier (Walters 1991), but new analyses are included to allow a direct comparison with seagrass blade and sediment data. Resident fauna on $T$. testudinum were sampled in a manner similar to that of Hall \& Bell (1988) by placing a clear plastic tube filled with filtered seawater over haphazardly chosen individual blades that were then excised at the sediment surface. Sediment samples were taken from an undisturbed area adjacent to emergence traps using a $6.2 \mathrm{~cm}^{2}$ corer to a depth of $3.5 \mathrm{~cm}$. A total of 5 emergence, 8 to 10 blade, and 8 to 10 sediment samples were collected at the end of each sampling period. Data were standardized to numbers per $10 \mathrm{~cm}^{2}$ sediment or seagrass blade surface. Emergence, blade, and sediment data were used to test whether copepod emergence coincided with increased numbers on seagrass blades and decreased numbers in the sediments

Field experiments. Copepod emergence, horizontal transport, and settlement onto sediments or seagrass blades were examined on 20-21 April 1987. During the study tides ranged from $0.6 \mathrm{~m} \mathrm{MLW}$ (ca $75 \mathrm{~cm}$ of water at the study site) at $17: 11 \mathrm{~h}$ before the start of 


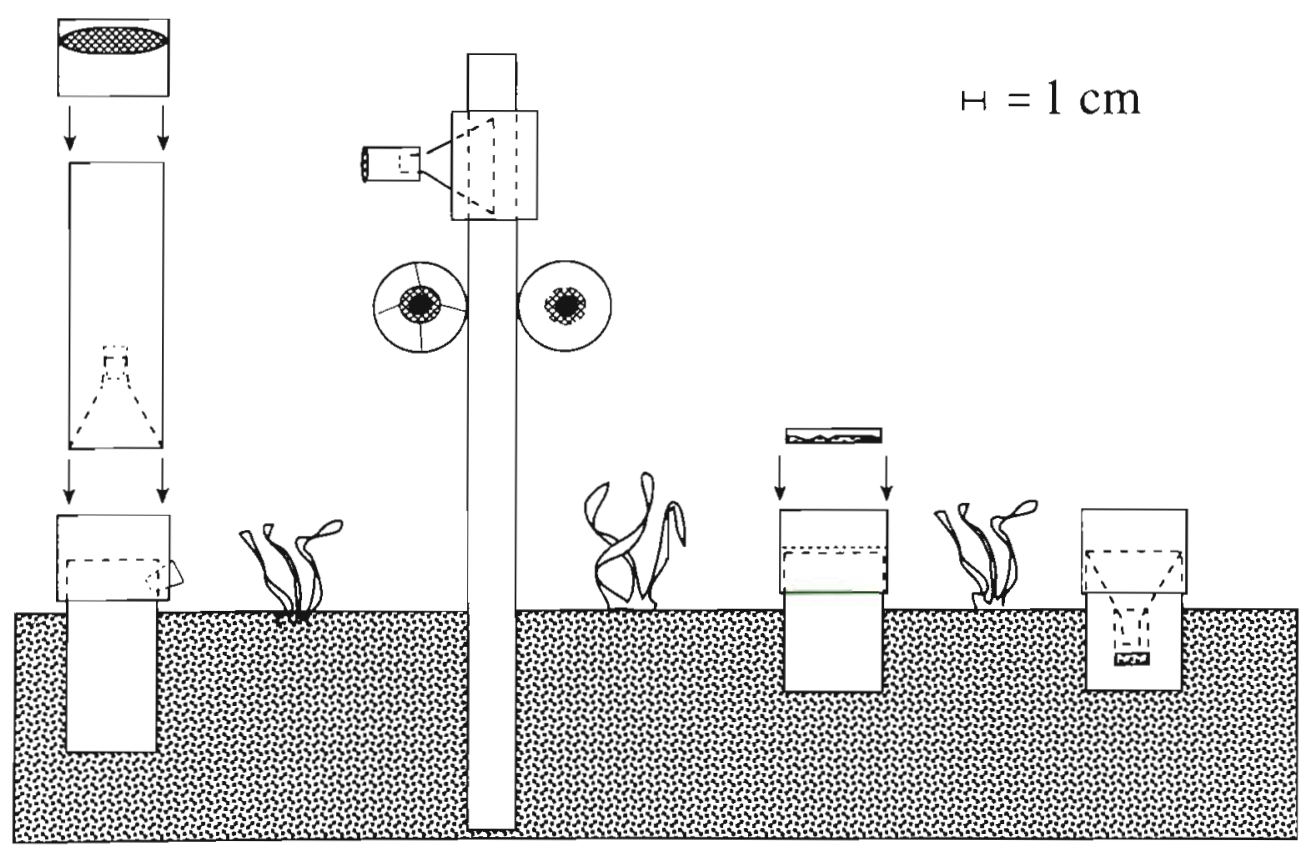

Fig. 2. Scale representation of the various collectors used to trap emerging copepods. From left to right are the emergence trap, horizontal collector array, and petri and funnel settlement traps. (See 'Methods' for details)

sampling to $0.1 \mathrm{~m} \mathrm{MLW} \mathrm{(ca} 25 \mathrm{~cm}$ of water at the study site) at 02:26 h. Emerging copepods were collected in traps ( $n=5$ ) only during $2 \mathrm{~h}$ presunset and postsunset periods as described previously.

Organisms transported in the water column were sampled by horizontal traps positioned above both sediments and seagrass blades (Fig. 2). Each trap consisted of an $82 \mathrm{~cm}^{2}$ PVC collar horizontally attached to a stake placed within the seagrass bed into which a $100 \mathrm{~mm}$ polypropylene funnel and attached collection jar were fitted. To enable water but not organisms to flow through the trap, the bottom of the collection jar was removed and fitted with $63 \mu \mathrm{m}$ mesh. Two arrays of 4 traps facing north, east, south, and west were placed in the field for $2 \mathrm{~h}$ periods. Prevailing water movement in the seagrass bed on outgoing tides when samples were collected is to the east-southeast (Fig. 1). Collection of greater copepod numbers was expected in traps facing the prevailing currents ( $N$ and $W$ ) if flow affected the water column dispersal of emerging copepods. Traps were positioned above the extended tips of seagrass blades, ca $30 \mathrm{~cm}$ above the sediment surface, to prevent the accidental collection of organisms directly from blades that might have contacted trap surfaces. Horizontal traps were deployed only during 2 periods covering sunset (20:00 to 22:00 h) and just after sunset (22:00 to 24:00 h). After 24:00 h, water levels prevented the placement of traps above seagrass blades. To determine if sediment-associated copepods were dispersed in the water column, data on the presence/absence of individual species in emergence and horizontal traps were compared.
Two cylinder traps with different collectors, petri dish and funnel, were employed to measure copepod settlement to the sediment surface (Fig. 2). Petri traps were similar to many open tray resettlement samplers that allow unrestricted faunal ingress and egress (e.g. Alldredge \& King 1980). Funnel traps were intended to restrict the reemergence of settled copepods but were not similar to settlement traps which have been shown to have a significant sampling bias (Gardner 1980a, Butman et al. 1986). Both traps consisted of a $10.7 \mathrm{~cm}$ diameter PVC base that was pushed into the sediments until ca $10 \mathrm{~cm}$ remained above the surface and into which petri or funnel collectors were placed. Positioning traps above the sediment surface prevented the inadvertent collection of nonemerging or seagrass blade copepods. In the petri traps, a $60.7 \mathrm{~cm}^{2}$ covered petri dish filled with heat-treated $\left(60^{\circ} \mathrm{C}\right.$ for $\left.>24 \mathrm{~h}\right)$ seagrass bed sediments and filtered seawater was placed on a wire mesh shelf $4.5 \mathrm{~cm}$ above the sediment surface inside the PVC base (Fig. 2). Heating the sediments killed resident copepods and rendered remaining exoskeletons easily identifiable. Funnel traps consisted of a $100 \mathrm{~mm}$ polypropylene funnel and collection jar similar to horizontal traps. The top of the funnel was placed $4.5 \mathrm{~cm}$ below the top of the PVC base and the collection jar filled with a small amount of heat-treated sediment (Fig. 2). Settlement samples ( $n=5)$ were collected and traps replaced every $2 \mathrm{~h}$ throughout the night beginning before sunset and ending after sunrise. Traps provided data on copepod species recruitment to the sediment surface that could be compared directly to data on benthic copepod emergence. 
Settlement trap design and placement represented a compromise between considerations of the hydrodynamic factors known to affect trapping efficiency, the physical characteristics of the seagrass environment, and the hypotheses being addressed. A suite of physical parameters including trap Reynolds number, particle fall velocities, and trap aspect ratio all can affect collection efficiencies (Gardner 1980a, b, Butman et al. 1986, Baker et al. 1988). The smaller the aspect ratio and greater the current velocity the greater the chance that particles will be resuspended and bias trap results (Gardner 1980b, Butman 1986). In areas of slack current flow such as the conditions under which our study was conducted, trap dimensions appear to be less critical to collection of an unbiased resettlement sample. Differences in trap aspect ratios (Gardner 1980a) or trap diameter for a fixed aspect ratio (Baker et al. 1988) had a limited effect on trapping efficiency at low $\left(<9.5 \mathrm{~cm} \mathrm{~s}^{-1}\right)$ current velocities. Although the aspect ratio of both traps was $<1$, maximum current velocities in seagrass beds typically are $<5$ to $6 \mathrm{~cm} \mathrm{~s}^{-1}$ and resuspension was not considered a major source of sample bias. Horizontal and vertical positioning and resultant secondary circulation patterns also can bias settlement trap results (Gardner 1980b, 1985). Our placement of traps $10 \mathrm{~cm}$ above the sediment surface was necessary to limit the collection of non-emerging or seagrass blade copepods. In low flow conditions, secondary circulation patterns likely would bias our results less then contamination of settlement traps with copepods that move or are transported along the sediment surface but do not emerge. Although physical factors affect the settlement of living organisms (Butman 1989, Yund et al. 1991), swimming and other behaviors also can influence trapping efficiencies (Fegley 1988, Coale 1990). A comparison between the 2 different settlement traps, one that restricted egress and one that did not, enabled us to examine the possible effects repeated emergence might have on copepod settlement patterns.

The movement of copepods onto and off Thalassia testudinum was examined using defaunated and natural blades. To defaunate blades, natural blades were collected from the field, treated with an $\mathrm{MgCl}_{2}$ solution (72 $\mathrm{g} \mathrm{l}^{-1}$ ) for 15 to $20 \mathrm{~min}$ to remove motile epifauna, and stored in $63 \mu \mathrm{m}$ filtered seawater for later use. Post-treatment examination indicated that copepods were removed effectively from defaunated blades. At the beginning of each sampling period defaunated blades were attached to $10 \mathrm{~cm}^{2}$ plastic mesh squares haphazardly placed within the seagrass bed and anchored into the sediments. Throughout the night 5 defaunated and natural blades were collected from the field after each $2 \mathrm{~h}$ sampling period using blade collection methods described above. Copepod numbers on seagrass blades were standardized per $10 \mathrm{~cm}^{2}$ of blade surface area and, along with species data, provided information on the movement of phytal copepods and the colonization of blades by emerging benthic and phytal copepods.

All samples were preserved in the field using a $10 \%$ buffered formaldehyde and rose bengal solution. In the lab, seagrass blades were agitated vigorously and visually inspected to remove all attached fauna. Sediment samples were processed using a shake and decant procedure (Wieser 1960) which removed greater than $95 \%$ of the copepods (Walters unpubl.). All copepods were enumerated at $25 \times$ and identified to the lowest taxon possible.

Statistical analyses. Copepod densities were analyzed using ANOVA and Ryan's $Q$ multiple comparison test (Day \& Quinn 1989) on appropriately transformed data. Nonparametric Kruskal-Wallis and Dunn's multiple comparison test procedures were used to compare all species densities because homogeneity assumptions of ANOVA were not satisfied by a majority of the individual species data. All tests were run on an IBM PS/2 using SAS 6.04 and the GLM or NPAR1WAY statistical routines (Joyner 1985). The statistical power of individual tests was calculated using Cohen (1988).

\section{RESULTS}

Harpacticoid copepods were the first or second most abundant group of adult metazoans in all samples and represented from 16.5 to $65.6 \%$ of all emerging, 2.4 to $30.9 \%$ of all seagrass blade, and 1.2 to $13.0 \%$ of all sediment fauna. In samples not dominated by copepods, nematodes and/or crustacean nauplii were the most abundant metazoans. Numbers of copepods emerging, on blades, or in the sediments varied between presunset and postsunset periods in 1983 (Fig. 3). Significantly greater numbers of copepods emerged during postsunset periods in March $(F=$ 10.93; df $=1,8 ; \mathrm{p}<0.05)$ and May $(F=48.28 ; \mathrm{df}=1,8$; $\mathrm{p}<0.0005)$, but not August $(F=2.63 ; \mathrm{df}=1,8 ; \mathrm{p}>0.1)$ or September $(F=4.32$; df $=1,8 ; \mathrm{p}>0.05)$. Copepod densities on postsunset seagrass blades increased significantly in March $(F=9.64$; df $=1,17 ; p<0.01)$ and August $(F=34.02$; df $=1,18 ; \mathrm{p}<0.0005)$ but did not increase on all dates (Fig. 3). Observed postsunset decreases in blade copepod densities were significant in September $(F=5.16 ; \mathrm{df}=1,18 ; \mathrm{p}<0.05)$ and not significant in May $(F=2.64 ; \mathrm{df}=1,16 ; \mathrm{p}>0.1)$. The average blade area sampled also varied among dates, from a low of $18.4 \mathrm{~cm}^{2}$ in March to a high of $70.7 \mathrm{~cm}^{2}$ in August. The presunset variation in copepod numbers on seagrass blades enabled detection of a $93 \%$ (March), 76\% (May), 54\% (August), and 50\% (Sep- 

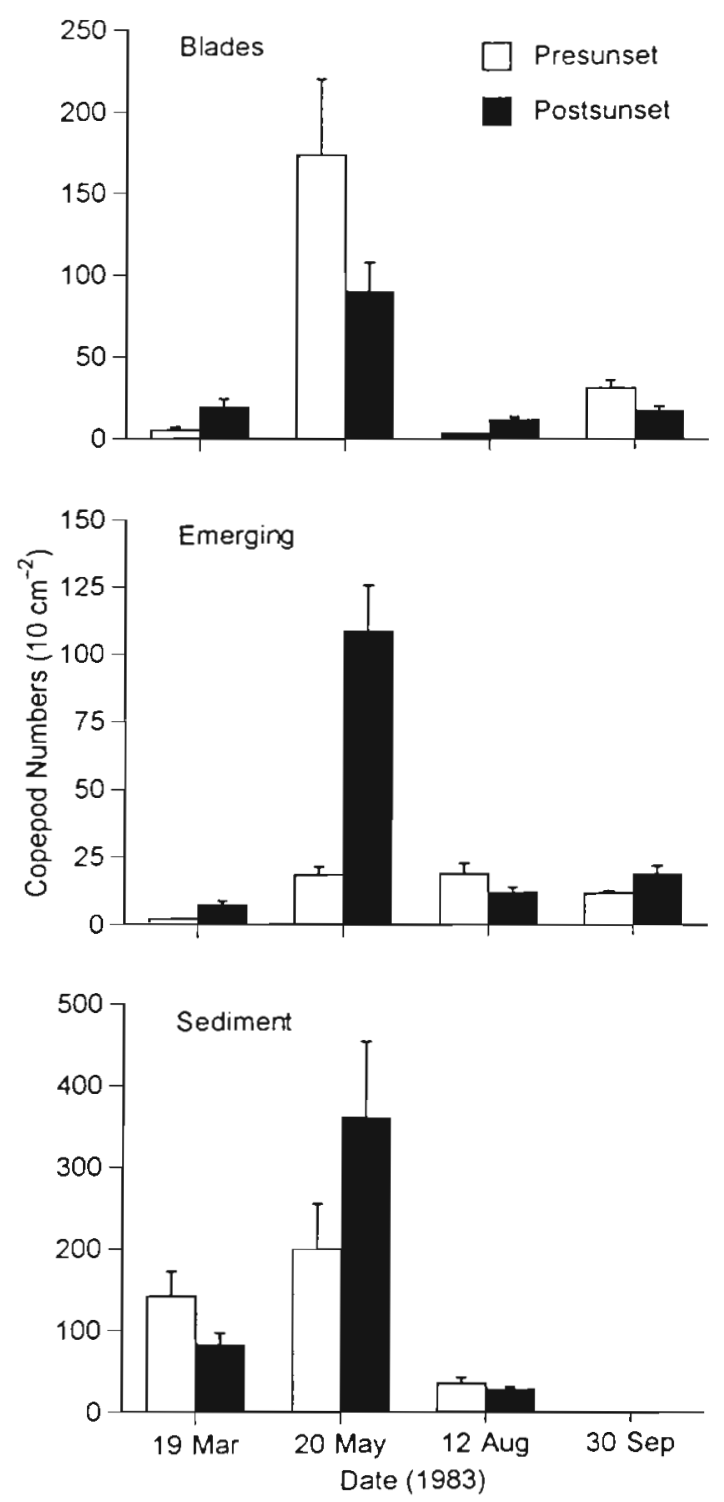

Fig. 3. Mean (+ SE) seagrass blade, emerging, and sediment copepod densities $\left(10 \mathrm{~cm}^{-2}\right)$ during $2 \mathrm{~h}$ presunset and postsunset sampling periods on 4 dates in 1983

tember) difference in densities with $80 \%$ power at the 0.05 level of significance. May and September density differences, $48 \%$, were not sufficient to be detected with reasonable statistical power. Presunset-postsunset differences in copepod sediment densities (Fig 3) were not significant in either March $(F=3.19$; df $=1,14$; $\mathrm{p}>0.05)$, May $(F=2.18 ; \mathrm{df}=1,14 ; \mathrm{p}>0.1)$, or August $(F=1.18 ; \mathrm{df}=1,18 ; \mathrm{p}>0.2)$. Given the presunset variation in sediment copepod densities we had a ca $20 \%$ chance of detecting a $7 \%$ decrease and a ca $75 \%$ chance of detecting a $30 \%$ decrease with an $\alpha=0.05$ and $\mathrm{n}=8$. The observed postsunset decrease in August copepod densities, $26 \%$, could not be detected with reasonable statistical power.
The composition of predominant emerging and seagrass blade species or species groups in 1983 was similar within but varied among sampling dates (Table 1). Combined densities of Mesochra pygmea, Ectinosomatidae spp., Harpacticus sp., Laophontidae spp., Metis holothuriae, Dactylopodia spp., and Tisbe furcata constituted between 30.0 to $74.9 \%$ of all emerging and 35.8 to $83.4 \%$ of all seagrass blade copepods. No consistent changes in species densities on blades coincided with the postsunset period of increased copepod emergence (Table 1). March densities of Ectinosomatidae spp. $\left(\chi^{2}=4.34, \mathrm{df}=1, \mathrm{p}<0.05\right)$ and Laophontidae spp. $\left(\chi^{2}=6.00\right.$, df $\left.=1, p<0.05\right)$ were significantly greater on postsunset blades, but neither species group emerged in significant numbers during either presunset or postsunset periods (Table 1). Densities of ectinosomatid spp. $\left(\chi^{2}=5.67, \mathrm{df}=1, \mathrm{p}<0.05\right)$ in May and Harpacticus sp. $\left(\chi^{2}=6.00, \mathrm{df}=1, \mathrm{p}<0.05\right)$ in September were significantly lower on postsunset seagrass blades while both species exhibited an increase in postsunset emergence from the sediments (Table 1). Only $M$. holothuriae densities in August suggested any connection between significantly greater densities on postsunset blades $\left(\chi^{2}=8.64, \mathrm{df}=1, p<0.005\right)$ and species emergence during presunset and postsunset periods (Table 1).

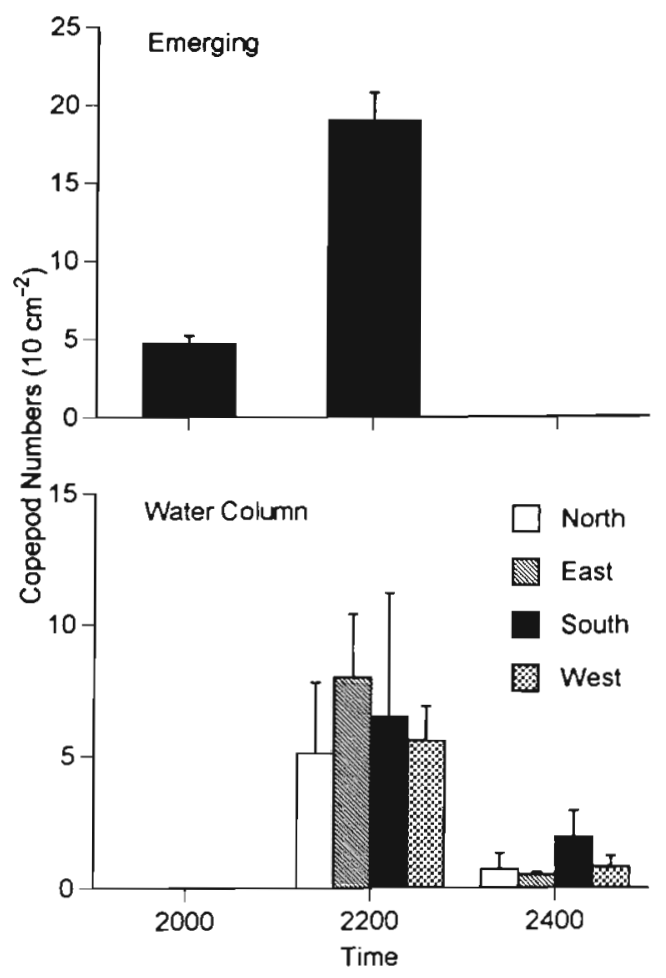

Fig. 4. Mean (+ SE) numbers of copepods $\left(10 \mathrm{~cm}^{-2}\right)$ emerging or horizontally transported in the water column during two $2 \mathrm{~h}$ sampling periods in April 1987 Sunset occurred during the period starting at 22:00 $\mathrm{h}$ 
Table 1 Mean (t SE) presunset and postsunset densities (per $10 \mathrm{~cm}^{2}$ sediment or blade surface area) for copepod species or species groups that constituted $>10 \%$ of the individuals found emerging or on seagrass blades during 1983

\begin{tabular}{|c|c|c|c|c|c|}
\hline \multirow[t]{2}{*}{ Date } & \multirow[t]{2}{*}{ Period } & \multicolumn{2}{|c|}{ Emerging } & \multicolumn{2}{|c|}{ Seagrass blades } \\
\hline & & Species/Group & Density & Species/Group & Density \\
\hline \multirow[t]{8}{*}{$19 \mathrm{Mar}$} & Presunset & Tisbe furcata & $0.0 \pm 0.0$ & Ectinosomatidae spp. & $1.6 \pm 0.8$ \\
\hline & & Mesochra pygmea & $0.2 \pm 0.1$ & Laophontidae spp. & $0.9 \pm 0.1$ \\
\hline & & Laophontidae spp. & $0.9 \pm 0.8$ & Harpacticus sp. & $2.2 \pm 0.6$ \\
\hline & & & & Dactylopodiaspp. & $1.1 \pm 0.4$ \\
\hline & Postsunset & Tisbe furcata & $2.5 \pm 0.6$ & Ectinosomatidae spp. & $6.3 \pm 2.4$ \\
\hline & & Mesochra pygmea & $1.5 \pm 0.3$ & Laophontidae spp. & $4.5 \pm 1.8$ \\
\hline & & Laophontidae spp. & $0.1 \pm 0.1$ & Harpacticus sp. & $2.0 \pm 0.6$ \\
\hline & & & & Dactylopodia spp. & $2.6 \pm 0.7$ \\
\hline \multirow[t]{6}{*}{20 May } & Presunset & Laophontidae spp. & $4.6 \pm 1.0$ & Laophontidae spp. & $53.2 \pm 17.4$ \\
\hline & & Ectinosomatidae spp. & $0.9 \pm 0.4$ & Ectinosomatidae spp. & $38.1 \pm 12.0$ \\
\hline & & & & Dactylopodia spp. & $29.2 \pm 10.2$ \\
\hline & Postsunset & Laophontidae spp. & $21.4 \pm 4.5$ & Laophontidae spp. & $17.5 \pm 3.8$ \\
\hline & & Ectinosomatidae spp. & $19.6 \pm 6.1$ & Ectinosomatidae spp. & $7.4 \pm 1.2$ \\
\hline & & & & Dactylopodia spp. & $7.4 \pm 1.0$ \\
\hline \multirow[t]{2}{*}{$12 \mathrm{Aug}$} & Presunset & Metis holothuriae & $5.3 \pm 1.5$ & Metis holothuriae & $0.6 \pm 0.2$ \\
\hline & Postsunset & Metis holothuriae & $2.5 \pm 0.8$ & Metis holothuriae & $4.5 \pm 1.3$ \\
\hline \multirow[t]{4}{*}{$30 \mathrm{Sep}$} & Presunset & Harpacticus sp. & $4.4 \pm 0.6$ & Harpacticus sp. & $13.5 \pm 2.3$ \\
\hline & & Dactylopodia spp. & $3.8 \pm 0.6$ & Dactylopodia spp. & $7.1 \pm 1.6$ \\
\hline & Postsunset & Harpacticus sp. & $5.4 \pm 1.1$ & Harpacticus sp. & $5.7 \pm 1.2$ \\
\hline & & Dactylopodia spp. & $3.8 \pm 0.5$ & Dactylopodia spp. & $5.1 \pm 1.3$ \\
\hline
\end{tabular}

Significantly greater numbers of copepods emerged ( $F=84.75 ; \mathrm{df}=1,8 ; \mathrm{p}<0.001)$ during the April 1987 postsunset sampling period (Fig. 4), but only Ectinosomatidae spp. $(38.0 \%)$ and Harpacticus sp. $(12.0 \%)$ constituted $>10 \%$ of all emerging copepods. Both Ectinosomatidae spp. $\left(\chi^{2}=6.86, \mathrm{df}=1, \mathrm{p}<0.01\right)$ and Harpacticus sp. $\left(\chi^{2}=6.36, \mathrm{df}=1, \mathrm{p}<0.05\right)$ emerged in greater numbers during the postsunset sampling period. Ectinosomatidae spp. were exclusively sediment-dwelling in April and constituted $<3.0 \%$ of the copepods found on blades. Harpacticus sp. were found both in the sediments and on seagrass blades and constituted $47.3 \%$ of all blade copepods.

A substantial number of either benthic or phytal copepods that entered the water column in April were collected in horizontal traps (Fig. 4). The compass orientation of horizontal traps did not affect the number of copepods collected $(F=0.20$; df $=3.8 ; p>0.5)$, but significantly greater numbers were trapped during the postsunset period $(F=11.86 ; \mathrm{df}=1.8 ; \mathrm{p}<0.01)$. Trap exposure by the ebbing tide for ca $30 \mathrm{~min}$ likely contributed to the decrease in numbers sampled during the period ending at 24:00 h. Ectinosomatidae spp. $(65.0 \%)$ and Harpacticus sp. $(9.4 \%)$ were the predominant copepods collected in horizontal traps.

Consistently greater numbers of copepods were enumerated from petri compared to funnel traps (Fig. 5). Among sampling periods significantly different numbers of copepods settled into petri $(F=4.14$; df $=6,26$; $\mathrm{p}<0.005)$ but not funnel traps $(F=1.06$; $\mathrm{df}=6,26$; $p>0.1$ ). Copepod densities in petri traps were significantly greater in postsunset and presunrise samples (Ryan's Q, p < 0.05). Ectinosomatidae spp. were $32.5 \%$ of all the resettled copepods and were the predominant taxa collected in either trap. Over twice the number of ectinosomatids settled into petri compared to funnel traps during the night (54 vs 21 ind. $10 \mathrm{~cm}^{-2}$ ). Harpacticus sp. was the only species found in greater

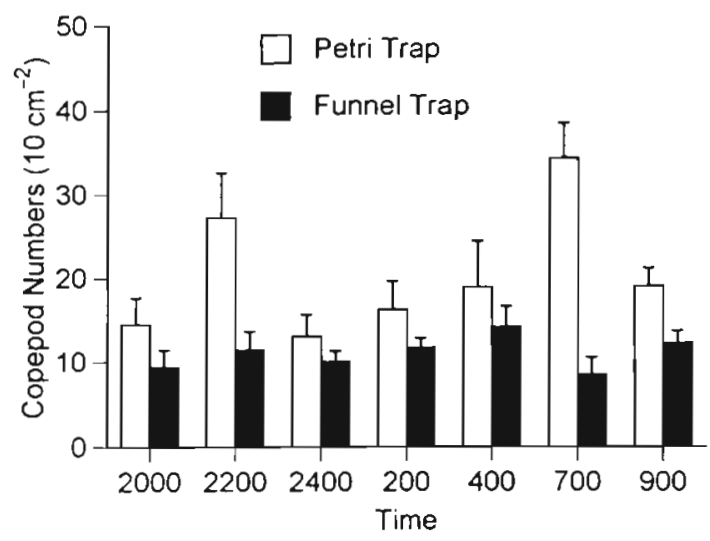

Fig. 5. Mean (+ SE) copepod numbers $\left(10 \mathrm{~cm}^{-2}\right)$ that settled onto funnel and petri traps during seven $2 \mathrm{~h}$ sampling periods in April 1987 Sunset occurred during the period starting at 22:00 h, sunrise during the period starting at $07: 00 \mathrm{~h}$ 
numbers within funnel traps, but mean densities were low ( 1 vs 2 ind. $10 \mathrm{~cm}^{-2}$ ). Postsunset and presunrise petri traps collected $200 \%$ more ectinosomatids than other periods, but there were no significant differences among sampling periods in the numbers of ectinosomatids that settled in either petri $\left(\chi^{2}=10.99, \mathrm{df}=6, \mathrm{p}>\right.$ $0.05)$ or funnel traps $\left(\chi^{2}=7.55, \mathrm{df}=6, \mathrm{p}>0.01\right)$. Taxa that exhibited a difference in settlement times typically settled in greater numbers sometime between 02:00 and $07: 00 \mathrm{~h}$ and included Laophontidae spp. $\left(\chi^{2}=\right.$ 15.07, $\mathrm{df}=6, \mathrm{p}<0.05$ ) in petri traps and Harpacticus sp. $\left(\chi^{2}=23.03, \mathrm{df}=6, \mathrm{p}<0.001\right)$, Dactylopodia spp. $\left(\chi^{2}=\right.$ 16.46, df $=6, p<0.05)$, and Tisbe furcata $\left(\chi^{2}=14.71\right.$, df $=6, p<0.05$ ) in funnel traps. Enhydrosoma herrerai and Zausodes arenicolus combined constituted only a small fraction of either the emerging $(4.1 \%)$ or blade copepods $(0.3 \%)$, but were an appreciable percentage of the copepods found in settlement traps $(9.8 \%)$. Settlement of $E$. herrerai was significantly different between sampling periods in both petri $\left(\chi^{2}=16.37\right.$, df $=6, p<0.05)$ and funnel traps $\left(\chi^{2}=18.95, \mathrm{df}=6, \mathrm{p}<\right.$ $0.005)$. Greater numbers of $E$. herrerai settled during presunset and postsunrise periods. $Z$. arenicolus only exhibited settlement differences in petri traps $\left(\chi^{2}=\right.$ $14.16, \mathrm{df}=6, \mathrm{p}<0.05)$ where greater numbers were collected during the presunrise period.

Copepod densities on natural and defaunated blades varied throughout the night (Fig. 6). On natural blades copepod densities between sampling periods were not significantly different $(F=2.02 ; \mathrm{df}=6,27 ; \mathrm{p}>0.05)$ and suggested limited movement onto or off of seagrass blades. A $32 \%$ difference in seagrass blade copepod densities could be detected with $80 \%$ power at the 0.05 level of significance. Sampling period differences in densities on defaunated blades were significant $(F=3.50 ; \mathrm{df}=6,27 ; \mathrm{p}<0.05)$ and greater numbers of

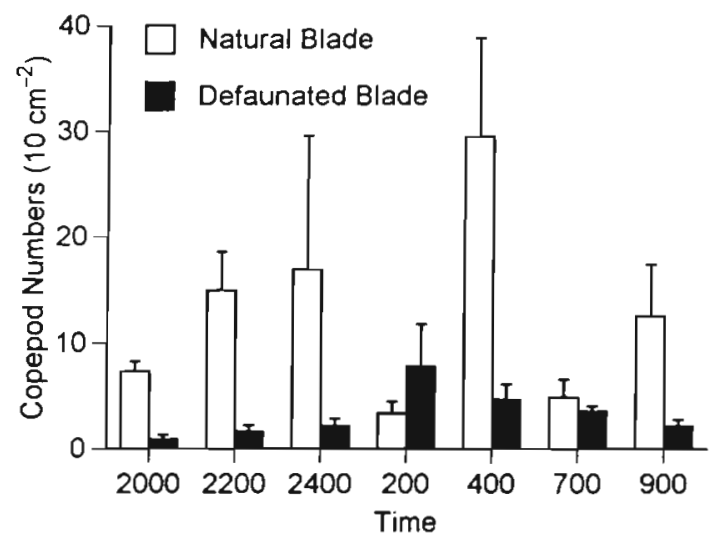

Fig. 6. Mean (+ SE) copepod densities $\left(10 \mathrm{~cm}^{-2}\right)$ on defaunated and natural seagrass blades during seven $2 \mathrm{~h}$ sampling periods in April 1987. Sunset occurred during the period starting at $22: 00 \mathrm{~h}$, sunrise during the period starting at $07: 00 \mathrm{~h}$ copepods settled onto defaunated blades after $24: 00 \mathrm{~h}$ (Ryan's $Q, \mathrm{p}<0.05$ ). Densities of both Harpacticus $\mathrm{sp}$. and Laophontidae spp., the predominant species on blades, were greater on natural blades. On defaunated blades Harpacticus sp. densities were significantly different between sampling periods $\left(\chi^{2}=19.88, \mathrm{df}=6\right.$, $p<0.005)$, but Laophontidae spp. densities were not $\left(\chi^{2}=3.63, \mathrm{df}=6, \mathrm{p}>0.05\right)$. Densities of Harpacticus $\mathrm{sp}$. along with Dactylopodia spp. and Tisbe furcata increased on defaunated blades between 04:00 and 07:00 h.

A summary of species-specific copepod linkages between benthic, pelagic, and phytal habitats from various studies is presented in Table 2 . Of the 21 species or species groups identified in Table 2, only 3 emerged from sediments or blades exclusively. Although there is an appreciable overlap in species composition between benthic and phytal habitats, 9 emerging species were not observed to resettle onto blades. Many species like Halectinosoma hydrofuge that did not resettle onto blades also did not disperse through the water column. Only 3 species exhibited unequivocal resettlement to the sediments, but $100 \%$ of the species for which data were available resettled to the sediments in at least 1 study. A difficulty in evaluating resettlement to the sediments was the inability to link emergence and settlement statistically. Significant numbers of Laophontidae spp. emerged during the April postsunset period in the present study $\left(\chi^{2}=\right.$ $5.91, \mathrm{df}=1, \mathrm{p}<0.05$ ), but statistically significant settlement to the sediments above presunset levels only occurred during the presunrise period (Dunn's, p < 0.05 ) and therefore can not be linked directly to increased postsunset emergence. The most striking observation from Table 2 is that $76 \%$ of the emerging species were found to disperse through the water column on at least 1 occasion.

\section{DISCUSSION}

The effects of sediment-dwelling metazoan emergence on linkages among benthic, pelagic, and phytal habitats will depend primarily on the numbers and fates of emerging individuals. For harpacticoid copepods in subtidal seagrass beds, postsunset emergence is a common behavior involving large numbers, $10^{4}$ to $10^{5}$ ind. $\mathrm{m}^{-2}$, and a significant percentage of the benthic population, 7 to $31 \%$ (Walters 1991). Emerging copepods can experience a number of possible fates that include pelagic dispersal and resettlement to either benthic or phytal habitats. In the present study we found that copepod emergence from benthic habitats resulted in (1) rapid (within hours) recolonization of benthic habitats by a significant portion of the 
Table 2. Summary of the linkages between benthic, pelagic, and phytal environments for subtidal (Bell et al. 1987, Kurdziel \& Bell 1992, this study) and intertidal seagrass bed copepods (Bell \& Hicks 1991). Resettlement was considered to occur if species' sediment or blade densities increased significantly during or just after periods of known emergence. Species that exhibited pelagic dispersal either were collected in horizontal traps, remained in the water column for prolonged periods of time, or colonized seagrass blades at a distance from a known source. ND: not determined; ? : conflicting data within or between studies (i.e. occurring on one date or in one study and not another)

\begin{tabular}{|c|c|c|c|c|c|}
\hline & \multicolumn{2}{|c|}{ Emergence from: } & \multicolumn{2}{|c|}{ Resettlement to: } & \multirow{2}{*}{$\begin{array}{c}\text { Pelagic } \\
\text { dispersal }\end{array}$} \\
\hline & Sediment & Seagrass & Sediment & Seagrass & \\
\hline \multicolumn{6}{|l|}{ Canthocamptidae } \\
\hline Mesochra pygmea & $? ?$ & ND & $? ?$ & No & No \\
\hline \multicolumn{6}{|l|}{ Cletodidae } \\
\hline Enhydrosoma herrerai & $? ?$ & No & Yes & No & No \\
\hline \multicolumn{6}{|l|}{ Diosaccidae } \\
\hline Bulbamphiascus sp. & Yes & Yes & ND & Yes & Yes \\
\hline Robertsonia hamata & Yes & ND & Yes & Yes & Yes \\
\hline \multicolumn{6}{|l|}{ Ectinosomatidae } \\
\hline Ectinosoma melaniceps & Yes & Yes & ND & No & Yes \\
\hline Halectinosoma hydrofuge & Yes & Yes & ND & No & No \\
\hline Ectinosomatidae spp. & Yes & $? ?$ & Yes & $? ?$ & Yes \\
\hline \multicolumn{6}{|l|}{ Harpacticidae } \\
\hline Harpacticus sp. & Yes & Yes & ?? & Yes & Yes \\
\hline Zausodes arenicolus & Yes & No & $? ?$ & $? ?$ & $? ?$ \\
\hline \multicolumn{6}{|l|}{ Laophontidae } \\
\hline Paralaophonte meinerti & ND & Yes & ND & Yes & Yes \\
\hline Paralaophonte sp. & Yes & Yes & ND & Yes & Yes \\
\hline Laophontidae spp. & Yes & ND & $? ?$ & No & $? ?$ \\
\hline \multicolumn{6}{|l|}{ Metidae } \\
\hline Metis holothuriae & Yes & Yes & $? ?$ & $? ?$ & Yes \\
\hline \multicolumn{6}{|l|}{ Porcellidiidae } \\
\hline Porcellidium sp. & No & Yes & ND & No & No \\
\hline \multicolumn{6}{|l|}{ Tegastidae } \\
\hline Tegastid sp. A & ND & Yes & ND & No & Yes \\
\hline Tegastid sp. B & ND & Yes & ND & No & Yes \\
\hline \multicolumn{6}{|l|}{ Thalestridae } \\
\hline Dactylopodia tisboides & Yes & Yes & ND & Yes & Yes \\
\hline Paradactylopodia brevicomis & Yes & Yes & ND & Yes & Yes \\
\hline Dactylopodia spp. & Yes & ND & $? ?$ & $? ?$ & ?? \\
\hline Idomene forficata & Yes & Yes & ND & No & No \\
\hline \multicolumn{6}{|l|}{ Tisbidae } \\
\hline Tisbe furcata & Yes & Yes & $? ?$ & Yes & Yes \\
\hline
\end{tabular}

emerging fauna, (2) active dispersal through the water column, (3) resettlement that is mediated by species behavior, and (4) nondetectable colonization of phytal habitats.

The inability to detect a postsunset decrease in sediment copepod densities or consistently increased densities on seagrass blades in March to August samples suggests that copepods rapidly, within $2 \mathrm{~h}$, resettled back to the sediments. On the dates sampled, between 7 and $31 \%$ of the copepod assemblage emerged during postsunset periods, which resulted in decreased sediment copepod densities inside emergence traps where resettlement was prevented (Walters 1991). A significant decrease between presunset and postsunset copepod sediment densities outside of emergence traps should have been observed unless insignificant numbers of copepods emerged, the statistical power of tests was low, phytal or other migrations compensated for numbers emerging from the sediments, or emerging copepods rapidly resettled. The nonsignificant difference between presunset and postsunset copepod numbers emerging in August and September was the result of an atypical increase in presunset emergence and not unusually low copepod emergence (Walters 1991). Although tests were able to detect small, $<10 \%$, density differences with limited statistical power, the proportion of sediment-dwelling copepods that emerged during May, $22 \%$, and August, 31\%, postsunset periods (Walters 1991) should have produced statistically detectable results. Phytal copepod densities also did not decrease significantly on postsunset blades, which would have indicated possible movement to the sediments, for dates when sediment copepod densities were available. The most parsimonious 
explanation for our inability to detect decreased sediment copepod densities during periods of increased emergence is that emerging copepods resettle rapidly Few diel differences in sediment copepod densities also occur in intertidal habitats, which suggests that resettlement from either hydrodynamic advection or emergence is rapid (Coull \& Feller 1988, Feller et al. 1990, Hicks 1992).

That copepods resettle quickly to the sediments is supported by April settlement trap results. Emerging copepods colonized petri traps in greater numbers just after sunset, typically the time of greatest emergence, and before sunrise. Copepod numbers emerging during the postsunset period (Fig, 4) were more than equaled by numbers that settled into traps (Fig. 5). Although postsunset data indicate a rapid resettlement of emerging copepods, the continued nighttime and increased presunrise settlement require explanation. Copepods typically emerge in greater numbers around sunset, but emergence can occur throughout the night (Walters \& Bell 1986, Walters 1988, 1991). The increased percentage of the copepod assemblage that emerges in traps deployed for $6 \mathrm{~h}$ (Walters \& Bell 1986) and the continued collection of emerging individuals from the same patch of benthos (Jacoby \& Greenwood 1988,1989 ) indicate that different individuals enter the water column during the night. Some copepod species also may remain in the water column after emerging (Bell et al. 1989) or exhibit differences in the timing of peak emergence (Walters 1988). Even after $9 \mathrm{~h}$ Bell et al. (1989) determined that $>75 \%$ of emerging Zausodes arenicolus individuals remained in the water column within field aquaria. Walters (1988) determined that $25 \%$ of all copepods that emerged from a seagrass bed entered the water column during the $2 \mathrm{~h}$ after sunset while $55 \%$ emerged during the remainder of the night. Assuming similar percentages for our April data, a mean of 61 copepods $10 \mathrm{~cm}^{-2}$ would have emerged during the hours between sunset and sunrise. During the same period, a total of 62 copepods $10 \mathrm{~cm}^{-2}$ resettled onto petri traps. The protracted settlement of copepods in traps likely reflects the night-long emergence patterns typical in subtidal seagrass habitats.

Although settlement occurred rapidly, emerging copepods did disperse through the water column (Fig. 4). Tidal or wind driven currents had a minimal effect on the pelagic dispersal of emerging copepods. All horizontal traps were deployed during an easterly sea breeze on an ebbing tide when prevailing currents at the study site were towards the southeast. If emerging copepods were transported as passive particles through the water column, greater numbers would be expected to accumulate in north-and/or west-facing traps. However, there was no difference in the numbers collected in traps with different compass orienta- tions. Equivalent numbers in traps facing north, east, south, and west suggest that emerging copepods haphazardly swam or moved through the water column. Our results differ from studies in hydrodynamically active sand habitats where the distribution of settling copepods is linked to flow (Fegley 1988, Savidge \& Taghon 1988, Kern 1990).

The difference in numbers and settlement patterns between petri and funnel traps indicated that species behavior affected the resettlement of emerging copepods. Although design constraints may affect settlement trap results, biases typically are more pronounced in turbulent flows (Gardner 1980a, Baker et al. 1988). Current velocities in the seagrass bed were not measured directly, but evidence suggests flows were well below critical erosion values on 20-21 April. Field flows were not strong enough to influence the directionality of copepods collected in horizontal traps, and surface conditions in the seagrass bed after 22:00 h were dead calm (Walters pers. obs.). Differences in copepod abundance between petri and funnel traps also were attributable to only one species group, the ectinosomatids. A systematic bias in collection efficiencies should have affected all copepod species equally. Without evidence to suggest a sampling bias, differences between petri and funnel traps likely reflect either selective settlement or post-settlement behavior. The almost 2 to 1 difference in Ectinosomatidae spp. settlement into petri traps may be related to the species' sediment-dwelling morphology (Bell et al. 1987). Although numerous in seagrass sediments throughout the year, ectinosomatids only emerge in any numbers from March to May (Walters 1991, this study) and only are abundant on seagrass blades between September and October (Hall \& Bell 1993). Morphology, restricted emergence, and a limited presence on seagrass blades all suggest that ectinosomatids prefer a sedimentary environment and may avoid settlement onto the artificial surfaces in a funnel trap. Whatever the reason, ectinosomatids exhibited a uniquely different settlement behavior compared to other emerging copepod species.

Some copepod species exhibited a limited emergence into the water column in April but were collected in appreciable numbers in settlement traps. Enhydrosoma herrerai and Zausodes arenicolus constituted $<5 \%$ of the emerging but often $>10 \%$ of the settling copepods. Previous studies have documented that $Z$. arenicolus is an active migrator in seagrass habitats (Service \& Walters 1991), but E. herrerai typically is not an emerging species (Bell et al. 1987, Walters 1991). The increased settlement in presunrise traps suggests that $Z$. arenicolus emerged later in the evening. Increased presunset and postsunrise numbers of $E$. herrerai settling suggest emergence during daylight 
hours, but E. herrerai also was collected in settlement traps throughout the night. The emergence behavior of $E$. herrerai may be limited to relatively short $(<15 \mathrm{~cm})$ distances off the sediment surface. Limited excursions would preclude collection in emergence traps, where vertical migrations of $>15 \mathrm{~cm}$ are required, but permit collection in settlement traps that were only $10 \mathrm{~cm}$ above the sediment surface. Seagrass copepods appear to exhibit a range of emergence behaviors, from the major excursions into the water column typified by ectinosomatids to the short jaunts above the sediment surface exhibited by E. herrerai.

Emergence of sediment-dwelling copepods is not linked to a consistent settlement onto seagrass blades. Postsunset emergence infrequently coincided with greater copepod numbers on blades. When blade copepod densities did increase in March and August the increase was not attributable to sediment-emerging species. Colonization of April defaunated blades also was not connected unequivocally to the emergence of sediment-dwelling copepods. Densities of Laophontidae spp., Dactylopodia spp., and Harpacticus sp., species that are both sediment (Walters 1991) and seagrass blade residents (Kurdziel \& Bell 1992, Hall \& Bell 1993), did not increase on blades during peak periods of emergence from the sediments. The pattern of recruitment onto defaunated blades cannot be explained by the postsunset increase in emergence unless Harpacticus sp., Dactylopodia spp., and Tisbe furcata remained in the water column for a protracted period of time; 22:00 h until 04:00 to 07:00 h. For individual copepod species within seagrass beds it is possible that sediments and blades represent distinct subpopulations only infrequently interconnected by emergence. Our inability to document an unambiguous exchange between sediment and seagrass populations of the same species suggests that not only species identity but habitat origin is critical to predicting the effects of emergence.

The interpretation of our blade colonization results may be complicated by differences in the availability of blade surface area, an inability to detect relatively small density differences between sampling periods, and/or the migration of blade-associated copepods. Differences in blade area influenced copepod density calculations and may have influenced settlement behavior, but March and August evidence for recruitment onto blades occurred on dates when the least and greatest blade area was sampled. If emerging copepods settled onto blades, numbers that would have produced density differences of from 50 to $93 \%$ could have been detected with reasonable statistical power. Given the range in detectable density differences, it is possible that settlement of a small percentage of the sediment-emerging copepods onto blades would go unnoticed. Copepod migrations off blades were not measured directly, but previous studies indicate phytal copepods are highly mobile (Gunnill 1982, Bell \& Hicks 1991, Kurdziel \& Bell 1992). An accurate assessment of migration effects would require measurement of copepod turnover rates on individual blades. Shortterm turnover rates for macrofaunal crustaceans on blades can exceed $50 \%$ of the assemblage (Howard 1985) and are linked to the colonization of seagrass blades (Edgar 1992), but turnover rates for meiofaunal copepods remain unknown.

Synthesis of the information available to date (i.e. Table 2) reiterates that the linkages among benthic, pelagic, and phytal habitats in seagrass systems are often species- and habitat-specific. An Ectinosomatidae sp. emerging from the sediments may not resettle onto seagrass blades, but one migrating off of blades may resettle to the sediments. Each habitat probably offers a unique set of resources and ecological interactions, but a large number of harpacticoid copepod taxa appear to participate in a continual reassortment both within and between benthic, pelagic, and phytal habitats. Detailed autecological studies on seagrass system copepods are critical for interpreting the importance of linkages between habitats and the patterns of habitat utilization that are suggested from field sampling and experimentation.

Benthic copepod species have been identified in the pelagic environment since the turn of the century (Brady 1899, Scott 1909), but the possible connections between emergence and water column dispersal were recognized only recently (Palmer 1988). Although sediment-emerging copepods appear to resettle rapidly, both water column dispersal (this study) and extended pelagic residence (Bell et al. 1989) can delay benthic reentry. Dispersal of migrating phytal copepods also results in prolonged water column habitation by normally benthic taxa (Bell \& Hicks 1991, Kurdziel \& Bell 1992). The pelagic dispersal of benthic copepods will increase the probability of interacting with both nektonic and planktonic assemblages. Consumption of emerging copepods by predatory nekton and zooplankton likely will increase with an increase in the time spent in the water column and may represent a significant trophic link between benthic and pelagic habitats. Fish in seagrass habitats can switch from preying on obligate zooplankton to preying on vertically migrating crustaceans (Robertson \& Howard 1978). Along with being consumed as prey, emerging copepods themselves may consume pelagic microbes. In nearshore coastal areas benthic copepods are associated with marine snow aggregates (Shanks \& Edmondson 1990) and can influence the dynamics of aggregate microbial assemblages (Walters unpubl.). Some intertidal sediment-dwelling copepod species 
feed on plankton and preferentially ingest pelagic diatoms during periods of tidal inundation (Decho 1986, 1988). While the emergence of sedimentdwelling copepods may affect both benthic and pelagic food webs, evaluating the magnitude of the effects will be difficult. Our study indicates that movements between benthic, pelagic, and phytal habitats occur rapidly and are difficult to detect without an extensive sampling regime. Determining the effects such movements have in each environment may be problematic and require the use of new techniques or unique experimental approaches.

Acknowledgements. We thank N. Edwards, J. Kern, and S. Service for field and laboratory assistance, D. Casey for technical drafting support, and K. Tenore, M. Palmer and 2 anonymous reviewers for comments on earlier drafts of the manuscript. The study could not have been completed without the cooperation of the Pinellas County Parks Department in allowing $24 \mathrm{~h}$ access to the field site. Partial support was provided by grants from the NOAA Coastal Ocean Program R/ERP-1 and NSF Biological Oceanography OCE 8017261A to S.S.B. and NSF Biological Oceanography OCE 9017807 to A. L. Shanks and K.W. This is Contribution No. 744 of the University of Georgia Marine Institute.

\section{LITERATURE CITED}

Alldredge, A. L., King, J. M. (1980). Effects of moonlight on the vertical immigration patterns of demersal zooplankton. J. exp. mar. Biol. Ecol. 44: 133-156

Armonies, W. (1988a). Physical factors influencing active emergence of meiofauna from boreal intertidal sediment. Mar. Ecol. Prog. Ser. 49: 277-286

Armonies, W. (1988b). Hydrodynamic factors affecting behaviour of intertidal meiobenthos. Ophelia 28: 183-193

Armonies, W. (1989). Meiofaunal emergence from intertidal sediment measured in the fjeld: significant contribution to nocturnal planktonic biomass in shallow waters. Helgoländer Meeresunters. 43: 29-43

Baker, E. T., Milburn, H. B., Tennant, D. A. (1988). Field assessment of sediment trap efficiency under varying flow conditions. J. mar. Res. 46:573-592

Bell, S. S., Hicks, G. R. F. (1991). Marine landscapes and faunal recruitment: a field test with seagrasses and copepods. Mar. Ecol. Prog. Ser. 73: 61-68

Bell, S. S., Hicks, G. R. F., Walters, K. (1988). Active swimming in meiobenthic copepods of seagrass beds: species patterns and role in reproductive behavior. Mar. Biol. 98 $351-358$

Bell, S. S., Hicks, G. R. F., Walters, K. (1989). Experimental investigations of benthic re-entry by migrating meiobenthic copepods. J. exp. mar. Biol. Ecol. 130: 291-303

Bell, S. S., Walters, K., Hall, M. O. (1987). Habitat utilization by harpacticoid copepods: a morphometric approach. Mar. Ecol. Prog. Ser. 35: 59-64

Brady, G. S. (1899). On the marine copepoda of New Zealand Trans. Zool. Soc. Lond. 15: 31-54

Butman, C. A. (1986). Sediment trap biases in turbulent flows results from a laboratory flume study. J. mar. Res. 44 645-693

Butman, C. A. (1989). Sediment-trap experiments on the importance of hydrodynamical processes in distributing settling invertebrate larvae in near-bottom waters. J. exp. mar. Biol. Ecol. 134; 37-88

Butman, C. A., Grant, W. D., Stolzenbach, K. D. (1986). Predictions of sediment trap biases in turbulent flows: a theoretical analysis based on observations from the literature. J. mar. Res. 44: 601-644

Cahoon, L. B., Tronzo, C. R. (1988). A comparison of demersal zooplankton collected at Alligator Reef, Florida, using emergence and reentry traps. Fish. Bull. U.S. 86: 838-845

Chandler, G. T., Fleeger, J. W. (1983). Meiofaunal colonization of azoic estuarine sediment in Louisiana: mechanisms of dispersal. J. exp. mar. Biol. Ecol. 69: 175-188

Coale, K. H. (1990). Labyrinth of doom: a device to minimize the 'swimmer' component in sediment trap collections. Limnol. Oceanogr. 35: 1276-1381

Cohen, J. (1988). Statistical power analysis for the behavioral sciences. Lawrence Erlbaum Associates, Hillsdale, NJ

Coull, B. C., Feller, R. J. (1988). Site-to-site variability in abundance of meiobenthic copepods along a tidal gradient over 24 hours. Hydrobiologia 167/168: $477-483$

Day, R. W., Quinn, G. P. (1989). Comparisons of treatments after an analysis of variance in ecology. Ecol. Monogr. 59: $433-463$

Decho, A. W. (1986). Water-cover influences on diatom ingestion rates by meiobenthic copepods. Mar. Ecol. Prog. Ser. 33: $139-146$

Decho, A. W. (1988). How do harpacticoid grazing rates differ over a tidal cycle? Field verification using chlorophyllpigment analyses. Mar. Ecol. Prog. Ser. 45: 263-270

Eckman, J. E. (1983). Hydrodynamic processes affecting benthic recruitment. Limnol. Oceanogr. 28: 241-257

Edgar, G. J. (1992). Patterns of colonization of mobile epifauna in a Western Australian seagrass bed. J. exp. mar. Biol. Ecol. 157: 225-246

Fegley, S. R. (1988). A comparison of meiofaunal settlement onto the sediment surface and recolonization of defaunated sandy sediments. J. exp. mar. Biol. Ecol. 123: $97-113$

Feller, R. J., Coull, B. C., Hentschel, B. T (1990). Meiobenthic copepods: tracers of where juvenile Leiostomus xanthurus (Pices) feed? Can. J. Fish. Aquat. Sci. 47: 1913-1919

Gardner, W. D. (1980a). Sediment trap dynamics and calibration: a laboratory evaluation. J. mar. Res. 38: 17-39

Gardner, W. D. (1980b). Field assessment of sediment traps. J. mar. Res. 38: 41-52

Gardner, W. D. (1985). The effect of tilt on sediment trap efficiency. Deep Sea Res. 32: 349-361

Gunnill, F. C. (1982). Macroalgae as habitat patch islands for Scutellidium lamellipes (Copepoda: Harpacticoida) and Ampithoe tea (Amphipoda: Gammaridae). Mar. Biol. 69: 103-116

Hall, M. O., Bell, S. S. (1988). Response of small motil epifauna to complexity of epiphytic algae on seagrass blades. J. mar. Res. 46: 613-630

Hall, M. O., Bell, S. S. (1993). Meiofauna on the seagrass Thalassia testudinum: population characteristics of harpacticoid copepods and associations with algal epiphytes. Mar. Biol. 116: $137-146$

Hicks, G. R. F. (1986). Distribution and behavior of meiofaunal copepods inside and outside seagrass beds. Mar. Ecol. Prog. Ser. 31: 159-170

Hicks, G. R. F. (1992). Tidal and diel fluctuations in abundance of meiobenthic copepods on an intertidal estuarine sandbank. Mar. Ecol. Prog. Ser. 87: 15-21

Howard, R. K. (1985). Measurements of short-term turnover of epifauna within seagrass beds using an in situ staining method. Mar. Ecol. Prog. Ser. 22: 163-168 
Jacoby, C. A., Greenwood, J. G. (1988). Spatial, temporal, and behavioral patterns in emergence of zooplankton in the lagoon of Heron Reef, Great Barrier Reef, Australia. Mar. Biol. 97: 309-328

Jacoby, C. A., Greenwood, J. G. (1989). Emergent zooplankton in Moreton Bay, Queensland, Australia: seasonal, lunar, and diel patterns in emergence and distribution with respect to substrata. Mar. Ecol. Prog. Ser. 51: $131-154$

Joyner, S. P. (1985). SAS/STAT guide for personal computers. SAS Institute, Inc., Cary, NC

Kern, J. C. (1990). Active and passive aspects of meiobenthic copepod dispersal at two sites near Mustang Island, Texas. Mar. Ecol. Prog. Ser. 60: 211-223

Kern, J. C, Taghon, G. L. (1986). Can passive recruitment explain harpacticoid copepod distributions in relation to epibenthic structure? J. exp. mar. Biol. Ecol. 101: 1-23

Kurdziel, J. P., Bell, S. S. (1992). Emergence and dispersal of phytal-dwelling meiobenthic copepods. J. exp. mar. Biol. Ecol. 163: 43-64

Lewis, J. B., Boers, J. J. (1991). Patchiness and composition of coral reef demersal zooplankton. J. Plankton Res. 13: $1273-1289$

Palmer, M. A. (1986). Hydrodynamics and structure: interactive effects on meiofauna dispersal. $J$. exp. mar. Biol. Ecol. 104: 53-68

Palmer, M. A. (1988). Dispersal of marine meiofauna: a review and conceptual model explaining passive transport and active emergence with implications for recruitment. Mar. Ecol. Prog. Ser. 48: 81-91

Palmer, M. A., Gust, G. (1985). Dispersal of meiofauna in a turbulent tidal creek. J. mar. Res. 43: 179-210

Robertson, A. I., Howard, R. K. (1978). Diel trophic interactions between vertically-migrating zooplankton and their fish predators in an eelgrass community. Mar. Biol. 48: $207-213$

Rutledge, P. A., Fleeger, J. W. (1994). Abundance and seasonality of meiofauna, including harpacticoid copepod species, associated with Spartina alterniflora stems. Estuaries 16: $760-768$

Savidge, W. B., Taghon, G. L. (1988). Passive and active components following two types of disturbance on an intertidal sandflat. J. exp. mar. Biol. Ecol. 115; 137-155

This article was presented by K.R. Tenore (Senior Editorial Advisor), Solomons, Maryland, USA
Scott, A. (1909). The Copepoda of the Siboga Expedition. Part I. Free-swimming, littoral and semi-parasitic Copepoda. Siboga Exped. Monogr. 29a: 1-323

Service, S. K., Bell, S. S. (1987). Density-influenced active dispersal of harpacticoid copepods. J exp. mar. Biol. Ecol. 114: 46-62

Service, S. K., Walters, K. (1991). Use of null models to assess patterns of size class migrations in the copepod Zausodes arenicolus. Mar. Ecol. Prog. Ser. 69: 17-23

Shanks, A. L., Edmondson, E. W. (1990). The vertical flux of metazoans (holoplankton, meiofauna, and larval invertebrates) due to their association with marine snow. Limnol. Oceanogr. 35: 455-463

Sherman, K. S., Coull, B. C. (1980). The response of meiofauna to sediment disturbance. J. exp. mar. Biol. Ecol. 46: $59-71$

Underwood, A. J., Fairweather, P. G. (1991). Supply side ecology and benthic marine assemblages. Trends Ecol. Evol. 4: $16-20$

Walters, K. (1987). Experimental investigations of vertically migrating meiofaunal populations in subtropical sand and seagrass habitats. Ph.D. thesis, University of South Florida, Tampa

Walters, K. (1988). Diel vertical migration of sediment-associated meiofauna in subtropical sand and seagrass habitats. J. exp. mar. Biol. Ecol. 117: 169-186

Walters, K. (1991). Influences of abundance, behavior, species composition, and ontogenetic stage on active emergence of meiobenthic copepods in subtropical habitats. Mar. Biol. 108: 207-215

Walters, K, Bell, S. S. (1986). Diel patterns of active vertical migration in seagrass meiofauna. Mar. Ecol. Prog. Ser. 34: 95-103

Webb, D. G., Parsons, T R. (1992). Winter-spring recruitment patterns of epiphytic harpacticoid copepods in a temperate-zone seagrass bed. Mar. Ecol. Prog. Ser. 82: 151-162

Wiens, J. A. (1989). Spatial scaling in ecology. Funct. Ecol. 3: $385-397$

Wieser, W. (1960). Benthic studies in Buzzards Bay. II. The meiofauna. Limnol. Oceanogr. 5: 121-137

Yund, P. O., Gaines, S. D., Bertness, M. D. (1991). Cylindrical tube traps for larval sampling. Limnol. Oceanogr. 36 : $1167-1177$

Manuscript first received: July 15, 1993

Revised version accepted: February 21, 1994 